\title{
Perception of Stakeholders on Abandoned Housing Projects in Malaysia
}

\author{
Noraini Mohd Ariffin \\ International Islamic University Malaysia, Malaysia, norainima@iium.edu.my \\ Dzuljastri Abdul Razak, \\ Mohamed Noorden Mohamed Imtiyaz \\ International Islamic University Malaysia, Malaysia
}

Article History

Received: May 8, 2019 Revised: June 24, 2019 Accepted: July 19, 2019

\begin{abstract}
Home is a basic necessity for everyone. However, one of the major issues affecting the construction industry in Malaysia today is that of abandoned housing projects. This issue has caused sufferings to the individuals and society. Several reasons have been cited for the abandoned housing projects, which include the debt financing structure, lack of justice and fairness, and weak regulatory system. The issues of the Islamic banking debtbased home financing products have remained prominent. There are also other issues such as role of the authority in addressing the situations. This study used mixed method of surveys and interviews in determining the perceptions of stakeholders regarding abandoned housing projects in Malaysia. The outcome of study highlights various prospects of mitigating the problem of abandoned housing projects. The findings show that the main cause of abandoned housing project from the interview with the relevant stakeholders is still due to insufficient legal provisions and protection to avoid and prevent abandonment of the housing projects, which is consistent with the previous studies.
\end{abstract}

Keywords: abandoned housing projects; causes; Islamic banks; regulations JEL Classification: G21; 138; R3

@ IJIEF 2019 published by Universitas Muhammadiyah Yogyakarta, Indonesia All rights reserved

DOI:

https://doi.org/10.18196/ijief.2118
Web:

http://journal.umy.ac.id/index.php/ijief/article/view/6252

Citation:

Ariffin, N. M., Razak, D. A., \& Imtiyaz, M. N. M. (2019). Perception of Stakeholders on Abandoned Housing Projects in Malaysia. International Journal of Islamic Economics and Finance (IJIEF), 2(1), 131-148. Doi: https://doi.org/10.18196/ijief.2118. 
Ariffin, Razak, \& Imtiyaz | Perception of Stakeholders on Abandoned Housing Projects in Malaysia

\section{Introduction}

Though the Malaysia housing sector has achieved tremendous strides over the years by making housing affordable to large part of the population, the issues of abandoned housing projects (AHPs) still exist. As a result, many buyers have become victims of AHPs.

There is no generally agreed definition of abandoned housing in the literature (Morckel, 2014). This is the reason why various researchers came up with uncountable operational definition to represent or serve as proxy for abandoned housing. Mallach (2006) for instance defined abandoned projects as those property whose owner has stopped carrying out at least one of the significant responsibilities of property ownership, as a result of which the property is vacant or likely to become vacant In another study, Marcuse (1985) defined abandoned projects as property where the owner is willing to surrender title to it without compensation because of the absence of effective demand for its continued use or reuse. Hence, researchers have used various operational definitions to represent the same construct. Based on the definition of Ministry of Housing and Local Government (MHLG), abandoned housing has been defined as any housing projects that have the following features:

(i) Construction activities on site of the housing construction project have stopped for 6 (six) months or more consecutively, after the expiry of the Sale and Purchase Agreement (S \& P) executed by the developer and the purchaser or;

(ii) The developer has been put under the control of the Official Receiver and the Housing Controller is of the opinion that such developer cannot duly proceed with the execution of its obligations as a developer.

Therefore, by referring to MHLG, an abandoned project is defined as an uncompleted project or a project that under delaying. Basically, it classified into three categories by the MHLG where "Delay Project", "Ailing Project" and "Abandoned Project". For the "Delay Project", it is defined as project under 10\% until $30 \%$ delaying compare to the actual date that targeted mean that the project is still under progress in the catch up the delay. However, for "Ailing Project" is project which is under more than $30 \%$ delaying compare to the actual date that targeted or date of completion that stated in the Sales and Purchase (S \& P) agreement but it's still under progress diligent in completed the entire project. However, for "Abandoned Project", it is a project that fully stopped where no more work is carrying on the entire project anymore.

IJIEF: International Journal of Islamic Economics and Finance, 2(1), 133-148 | 132 
As at mid of 2014, a total number of 211 sick housing projects, 33,647 houses and 22,135 house buyers in Malaysia had been abandoned by the private developers for various reasons (MHLG, 2014). The issue of abandoned housing is burdensome not only to the homebuyers but also to the government and the society. For instance, home owners are required to pay back the loans despite the fact that, there is no guarantee of completion and handing over of the house. In addition, the problem of abandoned housing can jeopardize government efforts of developing the housing sector. It is no doubt that increasing rate of abandoned housing project has posed serious headache to the government.

There are various reasons causing AHPs and the consequential problems they have caused are grave. One of the reasons is that there are insufficient legal provisions and protection to avoid and prevent abandonment and to protect the interests of the buyers. In the case of Malaysia, there are already few studies discussing the causes and issues on AHPs in the past. However, this study would like to examine whether the causes and issues are linked with the Shariah contract for home financing offered by Islamic banks to house buyers.

Therefore, this study willexamine the perceptions of stakeholders on the causes and issues on AHPs, including the Shariah contract used for home financing in Islamic banks.

\section{Literature Review}

\section{Debt Based Financing}

Ali et al. (2004) studied on contractor's perception of contributing factors to delayed projects. According to their findings, slow collection, low profit margins and insufficient capital or excessive debt are the three major causes of financial difficulties among contractors. Some of the contractors are overburden with debt due to excessive interest rate and other loans condition. In addition, it is equally stated that poor site management significantly contribute to the problem of abandoned housing project. This might be due to the possibility of transferring the bulk of the problems to the home buyers. As such, the contractors care less about effective site management since they are going to be less affected if the project is abandoned. If the contract is structured based on profit -loss sharing basis, all parties might take site management serious in order to protect their respective investment. 
In addition, several studies pointed that abandoned housing problems are mainly due to the nature of the contract i.e. Sell Then Buy (STB) system) (Sufian and Sapian, 2009). According to several commentators, the STB system has caused unbearable damages to households (Sufian and Sapian, 2009). Example of the problem witnessing is the situation where developers collect deposit from purchasers and then disappears. As such some developers collect booking fees and deposit with completing delivering the projects.

Based on the review, abandoned project is due to interplay of various factors that mainly comprises of injustice in contract which transfer most of the risk to the house purchaser, ineffective regulatory system and the nature of the contract.

\section{Justice and Fairness}

Justice and fairness constitute an important element towards successful implementation of transactions or contract. The absent of fairness in any business dealing or contract may result to less commitment and subsequent failure of the project. In relation to AHPs, various studies have attributed justice as one of the main problems.

According to Dahlan and Aljunid (2010) who assessed Shariah and legal issues in the Bai BithamanAjil (BBA), BBA is marred with injustice and unjust to the customers. In the case of default for instance, the borrower has to repay the banks the whole amount of sale price which is usually higher than the purchase price in the Sales and Purchase agreement entered between the buyer and developer. The whole amount of the debt together with the margin portion should be limited to the repayment period which the house buyers has utilized, occupied and enjoyed rather than the blanket amount of the whole repayment period as contained in the Sales and Purchase agreement. Based on their findings, BBA is embedded with high level of uncertainty which constitutes to be one of the major grievances of the purchaser in AHPs. According to them, the position regarding the status of the house, the charge, the ownership, the purchaser, the bank and the developer in the BBA transaction are ambiguous. BBA contract is equally considered as unfair to the general public because the profit margin is higher than the debt owed. In addition, the purchasers are still required to pay monthly installment to the banks even if the housing project is subsequently abandoned. This thus makes the banks to worry less about the issue of abandoned housing since their monthly installment is guaranteed. The purchasers are therefore the victims in abandoned houses issues because they must continue paying the monthly installments but yet they cannot 
occupy the purported houses. In a situation where the return of the banks is tied to the performance of the contract, the banks will take appropriate measure before realizing money to the developers with more commitment to regularly evaluate the progress of the contract.

In support of the above argument, Razali (2011) indicated that the current system of house delivery (i.e. STB) has been acknowledged to have helped in making many people a house owner, but it has however shown to be unsustainable due to the high occurrence of delay and AHPs. According to the Razali (2011), STB system has been blamed for the rising cases of abandoned housing because it put the house buyers at the mercy of the developers. The system therefore makes it possible for the house buyers to bear the business risk of the developers through the progressive payment. This thus purely reflects injustice on the part of the house buyers.

The issue of injustice faced by the house buyers has been further expound by (Yap et al., 2010) that house buyers are the immediate victims in the event of abandoned projects. This is because the house buyers bear the business risk that is supposed to be borne by the developers, they (i.e. developers) take less measure to prevent the project from abandonment. This has resulted to lack of feasibility studies and mismanagement of financial resources. Despite the fact that the project is abandoned, the house buyers are mandated to service the bank loans. In addition, the house buyers are denied the benefits of potential property value appreciation and rental collection. Other aspect of injustice that contributes to abandoned project is high interest rate which affects the sales and cash flow of the project (Yap et al., 2010).

Similar view has been expressed by Tan (2011) who indicated that the main victims of abandoned are mainly of low and middle-income groups which bear large portion of the risk involved when buying a house. As further stated by Tan (2011), there are cases where developers employed substandard materials such as leaking roof and uneven flooring. This has been made possible due to the delivery system whereby developers receive money before completion of the project and lack of law that protect the house buyers for such breach of contract.

As argued by the Association of Abandoned Building Owners (AABO) in Malaysia, banks rather than buyers should bear the risk of AHPs. The banks care less about the AHPs since the bulk of the burden is born by the home buyers rather than the banks and the developers who have real direct control. The banks in most cases do not care about the viability of the housing projects since their regular payment by the home owners is 
guaranteed irrespective of the completion of the projects. According to the report, most victims of abandoned housing project recommended the Build Then Sell (BTS) model. Meanwhile, the president of the AABO argued that such a model would be too riskier for big project rather the solution on the risk sharing between the developers and the banks. This thus indicate that the prevalent injustice in term of transferring the bulk of the risk to the house buyers is a significant contributing factor to the problems of AHPs.

\section{Regulatory System of Housing Projects in Malaysia}

Another main cause of AHPs is lack of effective regulatory system. As indicated by Hoe (2013), lack of home indemnity insurance, no special tribunal for home buyers claims and lack of effective planning and land policy significantly contribute to AHPs. The existence of an effective special tribunal whereby errant developers will be penalized could serve as a deterrent to others. This may thus make the developers to take proper measure that could lead to the abandonment of the project. In addition, Tan (2011) identified some nature of the regulatory system such as ambiguous relationship between federal, state and local level, delay in the process and approval of application for land development, conversion, subdivision and issuance of titles that contribute to abandoned projects. The same view as been expressed by Khalid (2010) who relates weak institutional factors as one of the main causes of abandoned houses.

According to Abdul Hadi et al. (n.d), the causes of abandoned construction projects can be broadly grouped into five categories, which are mismanagement, unfavourable government policies, inefficient public delivery system, unfavourable economic conditions and financial problems.

Dahlan (2011) discovered that abandoned housing problems occur due to the housing provision system and legislations which are complex and problematic. The findings by Dahlan (2011) agreed with Loi (2000), Khalid (2010) and Tan (2011). Loi (2000) and Khalid (2010) had discovered that housing provision in Malaysia is highly regulated and it is governed by so many legislations. Loi (2000) described that the Malaysian Housing Industry is govern by more than 50-60 piece of legislation ranging from development license issuance to private developers, law of building and land to the environment and workers safety. Moreover, Loi (2000) stated that it is compounded by the fact that separate laws, policies, and controlled by federal, state and local government separately. 
From the previous studies, it can be concluded that the main factors contribute to AHPs are due to the nature of the contracts, financing from the banks, absence of fairness in any business dealing or contract may result to less commitment and subsequent failure of the project and finally, lack of effective regulatory system. Therefore, this study aims to confirm whether these issues have been resolved after few years.

\section{Methodology}

\section{Data}

This study utilized a self-structured questionnaire based on a 5 Likert scale. The questionnaires were distributed to a sample of 500 respondents that are selected based on stratified sampling methods. Random sampling is chosen in order to ensure that all parts of the population are represented which can help to enhance the efficiency. Five-point Likert scale was employed in the analysis of the questionnaires. In addition, several interviews were conducted with relevant stakeholders (solicitor, banker, developer and Ministry official) to complement the findings from the questionnaire.

\section{Method}

Based on a 5 Likert scale in the questionnaire, percentage of Disagree includes 'Strongly Agree' and Agree includes 'Strongly Agree' and 'Agree' are obtained from the respondents' answers In addition, the current research adopted the fundamental approaches in analysing the output from the interviewees. The analysis includes data reduction, transcription of interviews, data display and conclusion drawing. The data gathered from interview will be arranged and summarised according to categories as mentioned earlier: debt financing,justice and equity and regulatory system of housing projects in Malaysia. The researcher then analysed and interpreted the information provided by the respondents in accordance with the objectives of the study. 


\section{Results and Analysis}

\section{Debt Based Financing}

Table 1. Debt financing' issues on AHPs

\begin{tabular}{lccc}
\hline \multicolumn{1}{c}{ Concepts used } & Disagree (\%) & Neutral (\%) & Agree (\%) \\
\hline $\begin{array}{l}\text { By choosing an Islamic home financing it will } \\
\text { mitigate abandoned housing projects. }\end{array}$ & 8.8 & 23.2 & 68 \\
$\begin{array}{l}\text { Home financing based on profit-loss sharing } \\
\text { between the customers and bank can avoid cases } \\
\text { of abandoned housing projects. }\end{array}$ & 9.8 & 21.3 & 69 \\
$\begin{array}{l}\text { I prefer financing that is based on profit and loss- } \\
\text { sharing when purchasing a house. }\end{array}$ & 4.3 & 19.2 & 75.6 \\
\hline
\end{tabular}

Table 1 above showed that majority of the home buyers (68\%) share the opinion that by choosing Islamic home financing it will mitigate AHPs. This is however not precise as to which specific Islamic home financing concept they think will help mitigate AHPs. Thus, the second question gives a specific Islamic home financing concept to get the views of the respondents. As shown in Table 1, majority of the respondents (69\%) believe that home financing based on profit-loss sharing between the customers and bank can avoid cases of AHPs. Conversely, only $9.8 \%$ of the respondents disagree and $21.3 \%$ remained neutral about that statement. Finally, $75.6 \%$ respondents prefer financing that is based on profit and loss-sharing when purchasing a house as compared to only $4.3 \%$ who do not prefer. About $19.2 \%$ respondents remained neutral.

The above findings therefore mean that, while majority of the home buyers believe that choosing an Islamic home financing will help mitigate AHPs, they specifically prefer profit and loss-sharing concept. This is consistent with the findings of Ahmad and Hassan (2009). According to Ahmad and Hassan (2009) equity home financing such as Musharakah Mutanaqisah financing is a better alternative compared to debt-based home financing because in Musharakah Mutanaqisah financing, bank is a partner in owning the house with the customer. Hence by taking joint ownership, the issue of Bai al-Inah or legal trick that exist in Bai Bithaman Ajil can be avoid the problem of AHPs. Therefore, the use of Musharakah Mutanaqisah financing rather than Bai Bithaman Ajil concepts in Islamic home financing can help reduce the problem of AHPs.

The interview with the solicitor, banker, developer and Ministry official onthe main factors that cause AHPs in Malaysia is undertaken. For the 
solicitor, the main factor is the weak process of giving the license to the developers, even though they are not qualified to get the licence. This can lead to the AHPs. This is consistent with the response from the banker, which is in the opinion that the main factor is due to the capability or credibility of housing developers, and this can be related to easy licensing to them. The developer and the Ministry official perceived that the factor is related to the funds for the project.

\section{Solicitor}

"Answer is the cheap and easy process of licensing of developer from the government. Compared to other countries, it is very easy in Malaysia to get developer's license. So, there are a lot of unqualified developers who got the license. Selling the houses while they are in reality not qualified financially and capability wise. So basically, they are small companies with a very small fund but what they do is to collect 10 percent from each house purchaser and invest in other projects."

\section{Banker}

"Factors contributing to AHP is mainly related to capability or credibility of housing developers experience, finance and management, economy and geographical factors. I believe there is a need to enhance or review of existing government policies and guidelines, for more structured guidelines and controls in managing AHPs."

\section{Developer}

"In my opinion, abandoned house has been reduced and will happen mostly during financial crisis. In my opinion the main cause of abandoned house is due mismanagement of funds where the funds are disbursed to the contractors rather than developers. These funds are then used for other purpose and not for the construction of the project."

\section{Ministry Official}

"The main reason for abandoned project is because of cash flow of housing developer as it is not well managed. There are also other issues, sometimes the issues about technical, there are house already 90 percent completed but still abandoned. We even do not know, we have sometimes problem with agencies such as drainage unit, firefighter unit, TNB, etc. They are sometimes may be the cause."

However, from the interview findings, it can be concluded that the main factor is related to house developers and not much on the Shariah contract used by Islamic banks, whether the Islamic bank should use Musharakah Mutanaqisah financing rather than Bai Bithaman Ajil. 


\section{Justice and Equity}

Table 2. Justice and Equity's issues on AHPs

\begin{tabular}{lccc}
\hline \multicolumn{1}{c}{ Justice and equity } & Disagree (\%) & Neutral (\%) & $\begin{array}{c}\text { Agree } \\
\text { (\%) }\end{array}$ \\
\hline $\begin{array}{l}\text { Customers should be fully burdened for houses } \\
\text { that are abandoned }\end{array}$ & 89 & 9.5 & 1.2 \\
$\begin{array}{l}\text { Islamic home financing using BBA uphold justice } \\
\text { when the house is abandoned }\end{array}$ & 59.8 & 29.6 & 5.5 \\
$\begin{array}{l}\text { Islamic home financing based on profit and loss- } \\
\text { sharing contributes positively to the equitable } \\
\text { distribution of wealth and income }\end{array}$ & 1.8 & 14 & 83.8 \\
\hline
\end{tabular}

Referring to Table 2 above, $89 \%$ of the respondents disagree that customers should be fully burdened for houses that are abandoned. On the other hand, only $1.2 \%$ respondents agree to the statement and the rest of the $9.5 \%$ were neutral. Similarly, majority (59.8\%) of the respondents disagree that Islamic home financing using BBA uphold justice when the house is abandoned. However, only 5.5\% agree that it upholds justice while $29.6 \%$ stayed neutral. Considering the contribution of Islamic home financing based on profit and loss-sharing, $83.8 \%$ of the respondents agree to the statement that Islamic home financing based on profit and loss-sharing contributes positively to the equitable distribution of wealth and income.

As argued by $A A O B O$ report above, most victims of abandoned housing project recommended the Build Then Sell (BTS) model which can provide justice and equity. Therefore, the interview questions were asked to the relevant stakeholders on the issue whether 'Build Then Sell (BTS)' or 'Sell Then Build (STB)'and their responses are as follows:

\section{Solicitor}

"The former is always the best option. In the case of Singapore where they are financially capable, they don't have to go through all the process of guarantee. After completing about 90\% to 95\% of the project, only then they will sell it. This concept too has issues, first, it is the political reason. Second, it is due to the financial incapability or sustainability. In Malaysia this is difficult especially when it is involved small developers with limited budget relying on the payment progress and in addition, it is hard to commence it due to political reasons. Malaysian Government once announced about the "build and sell" concept during the time of Tun Abdullah Ahmad Badawi but later it becomes unperceivable. Third reason is the property speculation or the property flipping where some people are buying the property with the intention to sell it back with higher prices gaining lot of margins. (Property flipping becomes illegal and a fraud for profit scheme when a home is purchased and resold within a short time frame at an artificially inflated value)." 


\section{Banker}

"I would definitely agree to the said concept as a risk mitigation tool for AHP. This concept would be not an issue for Tier A or may be Tier B housing developers, as they could proceed with completion of their project due to their financial strength. It is greatly good for bank and also the house buyers, but in an effort to support the growth of potential developers, bank would still need to support in spreading wealth creation with proper credit rating. Hence "build then sell" concept is still greatly relevant to support new and potential developers."

\section{Developer}

"Yes, 'build then sell' concept will be able to solve the problem of abandoned house compared to the prevailing 'sell then build' concept as the consumer can guarantee the project will be completed soon. However, under the BTS concept, the small developers will not be able to survive because they require a lot of fund to finance the house development which is currently based on STB. If developer were to use the BTS, the price for house could also be higher as the developer will have to seek its own external financing. The developer will have to seek its own financing and will incur higher interest cost."

\section{Ministry Official}

"This concept of build and sell from my viewpoint will help the sellers who already have completed houses to sell their houses to the buyers. Hence, they no longer think of the issue of abandoned housing. However, this concept requires large funds for developer. Even though they can get a loan from bank to finance the project, they cannot roll the money to pay every month because they cannot claim from the buyer as provided now. Moreover, if the cash flow is stop accordingly, the project will be abandoned. For an example, for low or medium cost housing might can be overcome but for high cost housing cannot be overcome because they needed much funds or are expensive. Furthermore, the cash flow plays an important role. Developer must provide strong cash flow before applying the scheme. Let say if it can be implemented, I think it is no problem because this something can be guaranteed, giving security for the buyers as compared current practice which is leads to abandoned project and illegal house built."

Based on the above interview findings, the concept of BTS will prevent AHPS and can promote justice and equity. However, this BTS requires a lot of funding to the developer to complete the housing projects before selling the houses. This will require the support from the financial institutions. 


\section{Regulatory System of Housing Projects in Malaysia}

Table 3. Legal and Governance's issues on AHPs

\begin{tabular}{lccc}
\hline Legal and Governance & Disagree (\%) & Neutral (\%) & Agree (\%) \\
\hline $\begin{array}{l}\text { The track record and the legality of the } \\
\text { developer is important to avoid the case of }\end{array}$ & 0.3 & 5.8 & 93.9 \\
abandoned house & & & \\
$\begin{array}{l}\text { The bank must take legal action on the } \\
\text { developer if it fails to deliver the house on time } \\
\text { The existing laws and regulations are insufficient } \\
\text { to ensure justice (adl) to Islamic home financing } \\
\text { customers in cases of abandoned house }\end{array}$ & 1.2 & 18.8 & 80.9 \\
\hline
\end{tabular}

With reference to Table 3, whereas $5.8 \%$ of the respondents remained neutral with regard to the first statement in the table, $93.9 \%$ of the respondents agree that the track record and the legality of the developer is important to avoid the case of AHPs. However, $0.3 \%$ of the respondents disagree with this assertion. Secondly, while $1.2 \%$ respondents disagree with the second statement, $89.9 \%$ of the respondents agree that the bank must take legal action on the developer if the developer fails to deliver the house on time. Nevertheless, $8.8 \%$ respondents neither agree nor disagree with the statement. With regard to the third statement, $1.8 \%$ respondents disagree while $80.2 \%$ respondents agree that the existing laws and regulations are insufficient to ensure justice $(a d l)$ to Islamic home financing customers in cases of abandoned house.

Considering the above results, the responses to all the three statements points out to the fact that it is important to have proper laws and regulations in order to avoid the cases of AHPs. However, the present laws and regulations are insufficient. This situation therefore contributes to the rampant cases of AHPs. These findings are consistent with some of the previous studies such as Khalid (2010), Tan (2011) and Hoe (2003) who have documented that lack of legal and governance for housing projects is among the reasons for the cases of AHPs in Malaysia.

This is supported by Chen (2007), who claimed that the Tribunal for Homebuyer Claims has proven to be very effective. It is however believed that the developers being sued are often insolvent and getting compensation is highly unlikely. However, the solicitor was in the view that there is lack of legal and regulatory provisions to reduce AHPs. 
Ariffin, Razak, \& Imtiyaz | Perception of Stakeholders on Abandoned Housing Projects in Malaysia

Above findings are further supported by following summaries of interviews had with industry stakeholders on the sufficiency of the regulatory protection for customers for housing development projects.

\section{Ministry Official}

"We indeed have an act 118 about housing development. I think already enshrined in to the act which is covering housing development projects. My own view for these victimized buyers, for example in my division, we pay more attention to buyers that buy low cost home. We are more concern to them because they come from low income group which sometimes need a house and are involved with abandoned house, they get problem. Therefore, if there are low cost abandoned house and still have no funds to be spent, the government will channel the funds to set the project up ready. In my own opinion, the government must be more aggressive going to the ground to inspect every project that is growing in the new region i.e. the growing area. That's why in some areas seem as goldmine. The buyer must actually be aware before buying, make sure to check and refer to national housing officer whether there is any realization of the project or not and do not just simply buy."

\section{Banker}

"Yes. There are certain measures. First, we have an account we call it house development account (HDA). This is one of the agreements of home financing. The payment from the customer will go to this account first and the developer doesn't have direct access to this account they only get the amount when the bank sees the progress. This is one of the basic government initiatives to manage the risk of home financing. And i think this is one of the reasons why the cases of abundant houses are decreasing."

\section{Developer}

"Yes, even currently the developer is already certified and licensed by the Ministry before they can undertake housing projects. However, there could be other issues that need to be looked it The Housing Development Act (HDA) does not allow the bank to go against the developers. Hence, I agree that we should look at the HDA to find out why this so."

\section{Solicitor}

"To be frank there is not such a thing in law. There are two scenarios. One is abandoned forever, which is the worst case the other one is the delay in completion. In case of forever the customer will sue the developer and he may get a good judgment from the court but by then, the developing company may be worth of nothing. I have seen one abandon project it was delay for 10 years. The customer was supposed to get $10 \%$ every year. So, at 
the end of 10 years by law the customer could claim $100 \%$ as late delivery charges. But the project was completed finally at that time and the developer didn't have the money to pay the customer. It is very tricky issue at the end they will negotiate. So, it is better for the customer to get $50 \%$ or $60 \%$ or otherwise they will lose the title."

With regard to the sufficiency of the regulatory protection for customers for housing development projects, it can be shown from the above interview findings that it is still not sufficient. Customers are not really protected based on the current regulation.

In addition, the interview question on the need of an independently rating scheme for developer based on performance can prevent AHPs is asked to the relevant stakeholders. The findings are as follows:

\section{Solicitor}

It is good in a way of convincing people that the rating is fair and clean to everybody. The rating system is based on the feedback of previous purchaser. For new developers with no record, the rating should be an indicative on how trustworthy they are. Hence, it is important that the rating is done by independent body or third party like ministry, or by the reliable consumer group, or third-party trustee. It cannot be done by the Association as they might be bias in the rating.

\section{Banker}

As a banker's point of view in supporting housing developers' financial needs, we categorized them into tiered categorization of tiers $A, B, C \& D$ with the application of difference credit rating in determining the amount/limit of financing to be granted.

\section{Developer}

Yes, an independently rating scheme for developer based on performance would help prevent abandoned house to safeguard the reputation of the developer. However, this also mean that we are grading our developer into various grades.

\section{Ministry Official}

Yes, perhaps it may help because we can see from history of successful in a project whether developer has a good track record. However, from my own observation, mostly developer has been successful in the first project to the third or the fourth project but to the fifth or sixth project may arise cash flow problem. It shows that authority of the first project and third project make 
they feel confidence about the project but in the fourth and fifth project they announce that it will arise some issues.

From the interview, it can be concluded that independent rating scheme for developer can overcome the problem of AHPs. This is because if the ratings are not good, then this developer will expose to reputational risk. Therefore, the developers will perform the best to complete the housing projects.

\section{Conclusion and Recommendation}

\section{Conclusion}

The focal issue of this study is on abandoned housing project (AHPs). The sufferings of the victims of AHPs who bought houses through bank financing are two folds. First, the house is abandoned and secondly, they have to carry the burden of huge debt. Even though the financing was availed from an Islamic bank but due to the debt-based nature of the contract, the victims have to pay all liabilities in full in the event the house is not completed. For example, in the popular home financing product like BBA, the bank does not share risk with customers... The Islamic banks in this case take no responsibility which goes against the core objectives in the fulfillment of Maqasid Al Shariah.

On the other hand, it was found that Musaharakah Mutanaqisah concept which is based on profit sharing isable to mitigate abandoned houses because the bank shares risk and responsibilities with customers. Hence, the bank will be responsible in cases for such occurrences. Hence, there is more justice and fairness in using the equity concept compared to debt financing which is also in line with Maqasid Al Shariah

Another important finding from this study is the need to improve the regulatory aspects to mitigate abandoned houses from incurring. Statutory provision provided by MHLG, Local Authority, planning authority and technical agencies had failed to strictly monitor the term in legal provision and requirements in the housing projects that can lead to AHPs.

However, based on the interview findings, it can be concluded that financial institutions are not the absolute players of the abandonment, but the use of the right Shariah contract, for example Musharakah Mutanaqisah can promote justice and fairness in the transactions. Therefore, weakness in the law remains the prime contributors to the problem of AHPs in Malaysia.

IJIEF: International Journal of Islamic Economics and Finance, 2(1), 133-148 | 145 
Ariffin, Razak, \& Imtiyaz | Perception of Stakeholders on Abandoned Housing Projects in Malaysia

\section{Recommendations}

It is suggested that the regulatory authorities should strengthen the law in order to protect the right of the home buyers to ensure justice and fairness. This can reduce the case of AHPs. In addition, the implementation of insurance and takaful cover to be undertaken by developers can prevent such occurrences. It also feasible to introduce ratings in order to screen developers based on their capabilities and track records in completing housing project.

Therefore, it will be a great advance for the society, industry and country, if efforts are made jointly by the civil and private sectors to end this problem of AHPs. 
Ariffin, Razak, \& Imtiyaz | Perception of Stakeholders on Abandoned Housing Projects in Malaysia

\section{References}

Abdul Hadi, A., Mohd Salleh, N. \& Mei, T. (n.d.). Abandoned Housing Project: Issues and Challenges. School of Housing, Building \& Planning University Science Malaysia.

Ali, A.S., Smith, A. \& Pitt, M. (2004.) Contractors' Perception of Factors Contributing to Project Delay: Case Studies of Commercial Projects in Klang Valley, Malaysia: University of Malaya.

Dahlan, N. H. M. (2011). Legal Issues in the Rehabilitation of Abandoned Housing Projects of the Liquidated Housing-Developer-Companies in Peninsular Malaysia. European Journal of Social Sciences,23(3), 392409.

Dahlan, N.H.M. \& Aljunid, S.Z.S.A.K (2010). Shariah and Legal Issues in Bay' Bithaman al-Ajil (BBA): A Viewpoint. Shariah Law Journal, 90-123.

Hoe, Y. E. (2013). Causes of Abandoned Construction Projects in Malaysia (Doctoral dissertation, Department of Surveying, Faculty of Engineering and Science, Universiti Tunku Abdul Rahman.

Khalid, M. S. (2010). Abandoned Housing Development: The Malaysian Experience Submitted in Fulfilment of the Requirements for the Degree of Doctor of Philosophy, Heriot-Watt University.

Loi, E. C. K. (2000). The State Housing and Property Industry presented in the National Conference on Housing and Urban Governance, Selangor, Malaysia.

Mallach, A., \& Brachman, L. (2010). Ohio's Cities at a Turning Point: Finding the Way Forward. Brookings: Metropolitan Policy Program.

Marcuse, P. (1985). Gentrification, Abandonment and Displacement: Connections, Causes, and Policy Responses in New York City. Washington University Journal of Urban and Contemporary Law, 28, 195-240.

Ministry of Urban Wellbeing, Housing and Local Government (MHLG) http://ehome.kpkt.gov.my/bi/main.php?Content=vertsections\&SubVe rtSection $\mid \mathrm{D}=103 \&$ VertSection $\mid \mathrm{D}=17$ \& CurLocation $=91 \& \mid \mathrm{ID}=\&$ Page $=1$ (Access on 08/05/2015).

Morckel, V. (2014). Predicting Abandoned Housing: Does the Operational Definition of Abandonment Matter? Community Development, http://dx.doi.org/10.1080/15575330.2014.892019.

Razali, M.F.M. (2011). Build Then Sell (BTS): Delivering Dream Homes with More Protection to House Buyers. Housing News, 11.

Sufian, A., \& Sapian, A. R. (2009). An Invention of "Build-Then-Sell" in Malaysia via the Housing Law, In proceeding of International Symposium in Developing Economies: Commonalities among Diversities, 103-108.

Tan, T. (2011). Sustainability and Housing Provision in Malaysia. Journal of Strategic Innovation and Sustainability, 7(1).

Yap, E.H., Tan H. C. \& Chia F.C.(2010). Causes of Abandoned Construction Projects. 
Ariffin, Razak, \& Imtiyaz | Perception of Stakeholders on Abandoned Housing Projects in Malaysia

This page is intentionally left blank

IJIEF: International Journal of Islamic Economics and Finance, 2(1), 133-148 | 148 